University of Nebraska - Lincoln

DigitalCommons@University of Nebraska - Lincoln

$6-2002$

\title{
Morphometric Analysis of Nonadult Characters of Common Species of American Gordiids (Nematomorpha: Gordioidea)
}

\author{
Ben Hanelt \\ University of New Mexico, bhanelt@unm.edu \\ John J. Janovy Jr. \\ University of Nebraska - Lincoln, jjanovy1@unl.edu
}

Follow this and additional works at: https://digitalcommons.unl.edu/bioscijanovy

Part of the Parasitology Commons

Hanelt, Ben and Janovy, John J. Jr., "Morphometric Analysis of Nonadult Characters of Common Species of American Gordiids (Nematomorpha: Gordioidea)" (2002). John Janovy Publications. 17.

https://digitalcommons.unl.edu/bioscijanovy/17

This Article is brought to you for free and open access by the Papers in the Biological Sciences at DigitalCommons@University of Nebraska - Lincoln. It has been accepted for inclusion in John Janovy Publications by an authorized administrator of DigitalCommons@University of Nebraska - Lincoln. 


\title{
MORPHOMETRIC ANALYSIS OF NONADULT CHARACTERS OF COMMON SPECIES OF AMERICAN GORDIIDS (NEMATOMORPHA: GORDIOIDEA)
}

\author{
Ben Hanelt and John Janovy Jr. \\ School of Biological Sciences, University of Nebraska-Lincoln, Lincoln, Nebraska 68588-0118. e-mail: bhanelt@un/serve.unl.edu
}

\begin{abstract}
The nonadult stages, egg strings, eggs, larvae, and cysts of Gordius robustus, Paragordius varius, and Chordodes morgani are described morphometrically. The goal was to document the differences between species and to evaluate the usefulness of morphometrics in species identification. In concert, multivariate analysis of variance (MANOVA) and univariate analysis of variance (ANOVA, a posteriori contrasts) statistical tests demonstrated that each species is morphometrically distinguishable from all others. Additionally, discriminant function analysis indicated that postseptum length, pseudointestine length, and stylet width were the most important variables in the discrimination of species based on larval characters. Finally, differences in oviposition behaviors among these 3 species were found. It is suggested that ovipositioning differences may place larvae into distinct niches and may ultimately lead to the use of different paratenic hosts by different gordiid species.
\end{abstract}

Gordiids are the freshwater-inhabiting members of the Nematomorpha. They are parasitic as larvae but free-living as adults. After mating, females expel egg strings within which larvae mature. After hatching, larvae encyst within a variety of aquatic animals. The life cycle is completed when terrestrial insect hosts consume cysts and become infected.

About 320 species of gordiids have been described globally (Bresciani, 1991). Only 14 species have been described from the United States (Chandler, 1985; Smith, 1991, 1994; de Miralles and de Villalobos, 1995). Of these, Gordius robustus Leidy, 1851, Paragordius varius Leidy, 1856, and Chordodes morgani Montgomery, 1898, are the most widely distributed species in the United States (Chandler, 1985). All 3 of these species have been reported from throughout the contiguous United States; from either coast and from southern states, Texas and Florida, to border states with Canada (see Chandler, 1985 and references therein).

The phylogenetic placement of the Nematomorpha is still uncertain. Cladistic analyses based on morphological and behavioral characters places the Nematomorpha sister to the Nematoda (Nielsen et al., 1996; Wallace et al., 1996). Using $18 \mathrm{~S}$ rRNA molecular data to support these findings has proven extremely difficult because of the unstable nature of this clade (Aleshin et al., 1998). However, several studies, based on molecular characters, have supported a close relationship between the Nematoda and the Nematomorpha (Winnepenninckx et al., 1995; Aleshin et al., 1998; Zrzavý et al., 1998). The most striking difference, however, between these 2 phyla is the presence of a larval stage within the life cycle of the Nematomorpha. The larval stage has pre- and postsepta, of which the preseptum contains rows of hooks (2-3) and a retractable proboscis (Schmidt-Rhaesa, 1997/98). Although the larval stage of the Nematomorpha is unique and has been indicated to be of substantial importance in some classification schemes (Malakhov, 1980), little attention has been focused on documenting this life cycle stage.

Adult forms of the 3 common American gordiid species have been described adequately. Studies of $P$. varius have included light microscopy and scanning electron microscopy (SEM) as well as sectioning (Montgomery, 1903; de Villalobos et al., 2000). Studies of the structure of adult $C$. morgani have also been done by light microscopy (Montgomery, 1898) and SEM

Received 9 October 2001; revised 19 December 2001; accepted 3 January 2002.
(Chandler and Wells, 1989). Gordius robustus adults have been studied using only light microscopy (May, 1919).

Nonadult life cycle stages have been less studied. Larval gordiids of these species have been described using light microscopy (Montgomery, 1904), SEM (Bohall et al., 1997; Adrianov et al., 1998), and transmission electron microscopy (Zapotosky, 1974, 1975). Even though cysts are a critically important part of this life cycle, they have never been thoroughly studied, although some investigations have indicated possible size differences among species (Poinar, 1991). Studies on the eggs or egg strings of these species have also never been conducted satisfactorily. Furthermore, none of these studies provide measurements of these life cycle stages.

Because adults can be difficult to find, but other life cycle stages can be encountered frequently (Hanelt et al., 2001), the present study was conducted to describe the nonadult life cycle stages. The focus of this study was on morphometrically describing eggs, larvae, and cysts. Also, differences in egg string morphologies and oviposition behaviors are described. Subsequently, features of the larvae were identified, using multivariate analysis to allow for the discrimination of species based on mensural data.

\section{MATERIALS AND METHODS}

\section{Specimen collection and maintenance}

Two populations for each species of gordiid were located and used in this study. Gordius robustus was collected from Las Huertas Creek $\left(35^{\circ} 16.44^{\prime} \mathrm{N}, 106^{\circ} 22.41^{\prime} \mathrm{W}\right)$, at Highway 44, Bernallio County, New Mexico, and $18 \mathrm{~km}$ southeast of Stillwater $\left(46^{\circ} 9.55^{\prime} \mathrm{N}, 96^{\circ} 51.28^{\prime} \mathrm{W}\right)$, Payne County, Oklahoma. Paragordius varius was collected from the women's shower room at Cedar Point Biological Station $\left(41^{\circ} 12.51^{\prime} \mathrm{N}\right.$, $\left.101^{\circ} 38.80^{\prime} \mathrm{W}\right), 2 \mathrm{~km}$ east of Lake McConaughy, Keith County, Nebras$\mathrm{ka}$, and from Millville Creek $\left(40^{\circ} 59.61^{\prime} \mathrm{N}, 96^{\circ} 33.93^{\prime} \mathrm{W}\right)$ at 112 th Street, Lancaster Country, Nebraska. Chordodes morgani was collected from Elk Creek $\left(40^{\circ} 53.13^{\prime} \mathrm{N}, 96^{\circ} 50.06^{\prime} \mathrm{W}\right)$, at Highway 34 , Lancaster County, Nebraska, and from Taylor Branch Creek $\left(40^{\circ} 10.67^{\prime} \mathrm{N}, 96^{\circ} 5.33^{\prime} \mathrm{W}\right)$ at Highway 4, Pawnee County, Nebraska. Adult worms collected from each population were deposited in the Harold W. Manter Laboratory (HWML) collection, University of Nebraska-Lincoln (G. robustus male: HWML 16557, female: HWML 16556; C. morgani male: HWML 16555, female: HWML 16554; and $P$. varius male: HWML 16553, female: HWML 16552).

For each species, worm pairs found copulating were isolated; the remaining worms were randomly paired and placed in 1,000-ml plastic containers containing well water, with aeration. Egg strings were collected from each mated pair and briefly rinsed in a 1:250:: Clorox ${ }^{\infty}$ bleach : well-water solution, as described previously (Hanelt and Janovy, 1999). A 60-ml glass jar, rinsed previously with the bleach solution, was used to keep a stock of larvae from each of the 3 species. All 


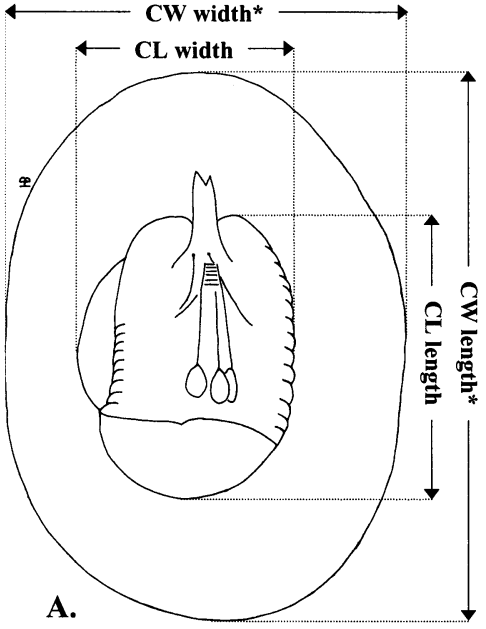

B.

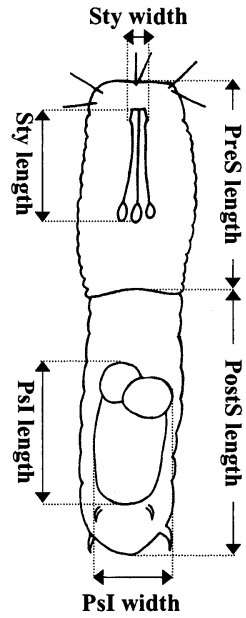

* see text about how CW length and width was calculated

Figure 1. Morphometric measurements for gordiids. (A) Cyst. (B) Larva. CL, cyst larva; CW, cyst wall; PostS, postseptum; PreS, preseptum; PsI, pseudointestine; and Sty, stylet. Note that diagrams are based on the cyst and larva of Paragordius varius.

eggs were stored in well water or in aerated commercial spring water at room temperature. Water was changed every $2-3$ days.

\section{Measurements and exposures}

For all species, measurements were taken from each of the 2 worm populations. All eggs $(n=90)$ and egg strings $(n=30)$ were measured as soon as possible after oviposition. Height and width measurements were taken for each egg. Larvae $(n=90)$ were measured just after hatching. Six measurements were taken for each larva (Fig. 1B). The pseudointestine had a different shape in all 3 species. In all cases, the maximum length and the maximum width of this structure were measured.

For the cysts $(n=50)$, measurements of the larva and the cyst wall were taken (Fig. 1A). The wall of the cyst will be termed the cyst wall. The larva within the cyst will be termed the cyst larva. Earlier, it was noticed that cysts normally had thicker cyst walls at the ends of the cyst larvae, i.e., dorsal and ventral, than on their sides, i.e., laterally. Thus, the thickness of the cyst wall was measured in 2 locations (1) parallel to the cyst (length) and (2) perpendicular to this measurement (width; Fig. 1A). To measure the thickness of the cyst wall, the maximum length and the maximum width of the entire cyst were measured. Subsequently, the length or width of the cyst larva was subtracted from these numbers, respectively, and each resulting number was divided by 2. This calculation provided the average thickness of the cyst wall for the height and the width of each cyst. Because the stylet length is unlikely to change through different life cycle stages, this character was only measured in the larvae, not in the cysts.

To obtain cysts, Physa gyrina were exposed to freshly hatched larvae. Groups of 20 snails were exposed to 300-500 larvae in a 90-ml plastic container, using well water or aerated commercial spring water. Snails were kept unfed for 5 days, after which the water was changed, and snails were fed flakes of Tetramin ${ }^{\star}$ fish food (Tetra Sales, Blacksburg, Virginia) and autoclaved lettuce every other day.

Approximately 14-30 days postexposure, snails were examined as previously described (Hanelt et al., 2001). Shells were removed from snails, and the soft tissue was crushed between coverslip and slide. Only those cysts, which lay perfectly flat, were measured. One group of exposed snails per gordiid species was used for all cyst data.

\section{Data analysis}

The resulting data were contained in 4 separate data sets, egg string, egg, larva, and cyst. The questions to be addressed using these analysis were (1) Are there significant differences among species based on all characters within each data set?, (2) Are there significant differences among species based on each character individually?, and (3) If a significant difference is found among species based on an individual character, which of the species are actually different from 1 another? To that end, data were subjected to a series of multivariate and univariate analyses using SAS (v. 6.12) software (SAS Inc., 1990).

To avoid problems associated with character correlation, significant differences among groups were first determined using multivariate analyses. For each data set separately, except the egg string data, a 1-way multivariate analysis (MANOVA) was performed to determine if significant differences exist among species, based on mensural characters. When a MANOVA was significant, corresponding 1-way analyses of variance (ANOVAs) were subsequently performed for each character alone to evaluate its potential contribution to differences among the 3 species. Furthermore, species that were significantly different from each other were identified using the least significant difference test and the Bonferroni (Dunn) test.

Data on larvae were also analyzed using discriminant function analysis (DFA). This analysis simultaneously maximizes differences among species and minimizes stepwise analysis. This analysis can help select the best species discrimination variable(s). This procedure will make it possible to determine which characters are most important in the discrimination among species of gordiids, considering the morphometric measurements of larvae. The degree to which species of gordiids could

TABLE I. Measurements of the eggs $(\mathrm{n}=90)$, larvae $(\mathrm{n}=90)$, cysts $(\mathrm{n}=50)$, and egg strings $(\mathrm{n}=30)$ of Gordius robustus, Paragordius varius, and Chordodes morgani. Means and ranges (in parentheses) are given in micrometers.

\begin{tabular}{lccc}
\hline & G. robustus & P. varius & C. morgani \\
\hline Egg string width & $599.4(380-901)$ & $225.5(152-277)$ & $485.8(375-578)$ \\
Egg length & $47.6(40.0-55.4)$ & $39.5(31.0-47.7)$ & $35.8(27.5-46.0)$ \\
Egg width & $37.9(33.8-46.3)$ & $29.3(22.5-36.0)$ & $28.1(21.5-33.5)$ \\
Preseptum length & $29.6(21.8-37.0)$ & $22.3(16.0-31.2)$ & $24.2(19.7-29.3)$ \\
Preseptum width & $17.8(15.5-21.5)$ & $13.9(10.9-17.9)$ & $13.4(12.2-14.5)$ \\
Postseptum length & $74.1(54.5-99.7)$ & $30.2(22.0-39.0)$ & $26.7(21.9-30.8)$ \\
Postseptum width & $14.3(10.5-16.5)$ & $11.4(9.8-15.8)$ & $11.2(3.0-9.5)$ \\
Stylet length & $13.1(10.4-17.0)$ & $12.6(10.5-14.7)$ & $11.6(10.3-13.4)$ \\
Stylet width & $4.1(2.6-5.2)$ & $2.9(2.1-3.9)$ & $3.6(2.8-4.4)$ \\
Pseudointestine length & $50.5(37.0-65.0)$ & $15.9(11.3-24.9)$ & $11.6(9.5-14.0)$ \\
Pseudointestine width & $11.0(8.0-16.6)$ & $7.4(5.4-10.9)$ & $8.0(6.0-9.5)$ \\
Cyst wall length & $14.8(9.0-23.0)$ & $13.7(5.0-20.7)$ & $7.3(3.0-15.6)$ \\
Cyst wall width & $10.3(4.5-15.0)$ & $9.2(4.7-12.9)$ & $5.8(2.5-10.6)$ \\
Cyst larva length & $36.7(31.2-43.8)$ & $26.7(23.4-29.7)$ & $25.9(24.2-31.3)$ \\
Cyst larva width & $28.6(23.4-36.7)$ & $19.3(16.8-22.6)$ & $21.3(17.5-25.0)$ \\
\hline
\end{tabular}


TABLE II. Significance levels of the character suite and each character separately in distinguishing among 3 species of gordiids (Gordius robustus, Paragordius varius, and Chordodes morgani).

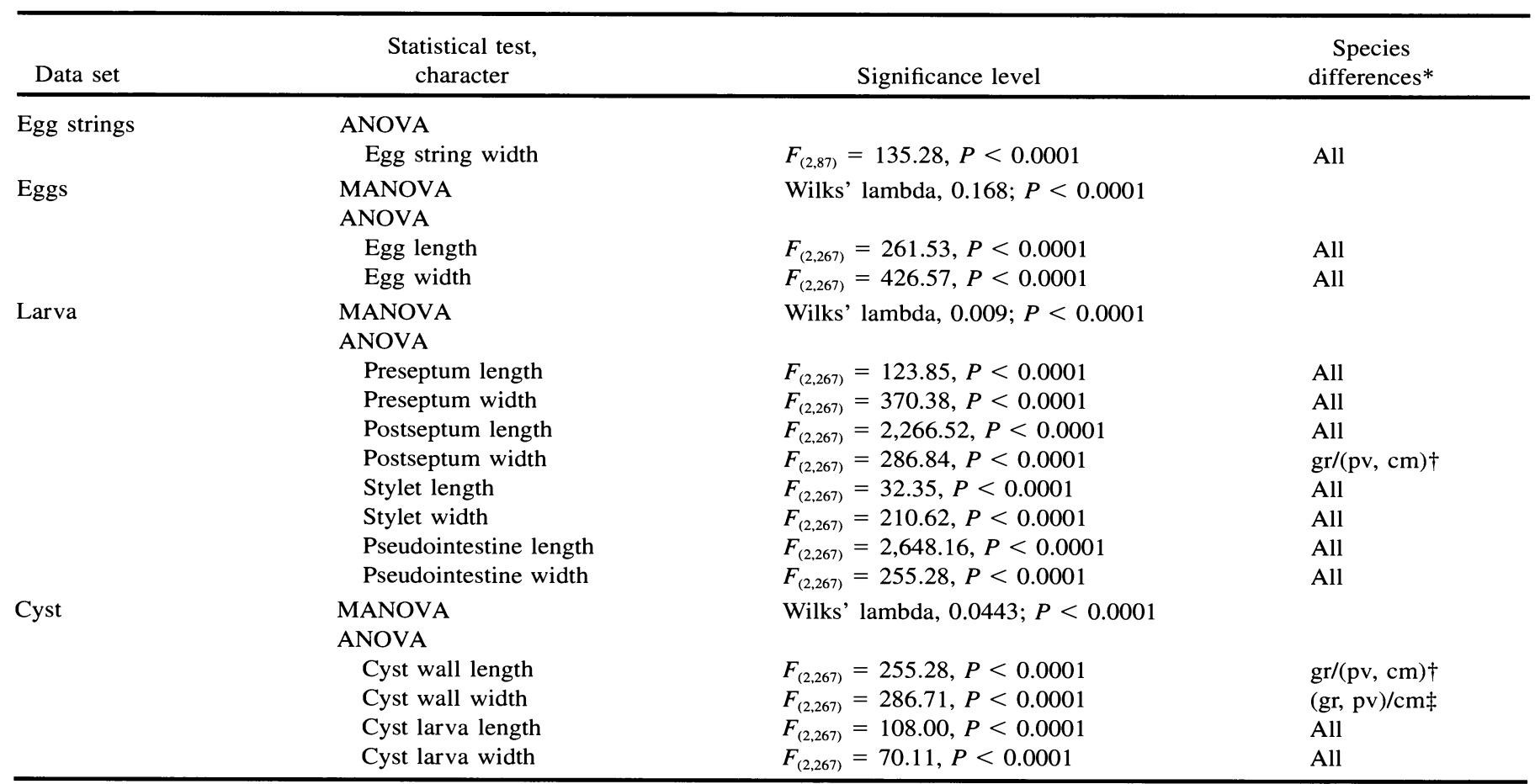

* Using the least significant difference test and the Bonferroni (Dunn) test.

$\dagger$ Significant differences were only found between $G$. robustus and the group of $P$. varius and $C$. morgani.

$\ddagger$ Significant differences were only found between $C$. morgani and the group of $G$. robustus and $P$. varius.

be separated based on larval characteristics was visualized using principal component analysis (PCA). If individuals of each species form distinct clusters in multidimensional space, the character suite is effective in discriminating among species. However, if the result is a severe overlap of taxa, then the suite of mensural characters may not be sufficient to enable the classification of species.

\section{RESULTS}

The means and ranges for all measurements for all species are given in Table I. Considering all measurements within each data set, highly significant differences existed among species based on egg, larva, and cyst measurements (Table II). Considering each character individually, highly significant differences also existed among species. All 15 characters of all 4 data sets were found to have significant differences when considered in-

TABLE III. Stepwise discriminant analysis of morphometric data of larvae of gordiids.

\begin{tabular}{lcrc}
\hline \multicolumn{1}{c}{ Variable } & Partial $r^{2}$ & $F$ statistic & $\begin{array}{c}\text { Probability } \\
>F\end{array}$ \\
\hline Pseudointestine length & 0.9520 & $2,648.16$ & 0.0001 \\
Stylet width & 0.4918 & 128.73 & 0.0001 \\
Postseptum length & 0.2541 & 45.14 & 0.0001 \\
Preseptum width & 0.1938 & 31.72 & 0.0001 \\
Pseudointestine width & 0.1531 & 23.77 & 0.0001 \\
Stylet length & 0.1089 & 16.01 & 0.0001 \\
Preseptum length & 0.1530 & 23.58 & 0.0001 \\
Postseptum width & 0.0322 & 4.32 & 0.0142 \\
\hline
\end{tabular}

dividually. Post hoc testing of this latter series of tests showed that all but 3 characters significantly differed among all 3 species. The exceptions were postseptum width, cyst wall length, and cyst wall width (Table II). The postseptum width of $P$. varius and $C$. morgani and the cyst wall length and width of $G$. robustus and $P$. varius were not found to be significantly different.

Of all 150 cysts measured, $111(74 \%)$ had thicker cyst walls at the ends of the cyst larvae, $4(2.7 \%)$ had cyst walls of equal thickness at the ends and the sides, and 35 (23.3\%) had thicker cyst walls at the sides of the cyst larvae.

DFA considered all larvae characters of value in the discrimination process (Table III). It also showed that pseudointestine length, stylet width, and postseptum length are variables that best separate the 3 species of gordiids.

PCA analysis shows that principal component 1 (PC1) accounted for 88.8 percent of the variation, and that the first 2 components account for 92.72 percent of the variation (Table IV). PC1 had positive values for all variables and was most positively weighted by postseptum length and the pseudointestine length. PC2 had both positive and negative values but was extremely positively weighted by stylet width. A plot of the canonical function shows that there was graphic separation between the 3 species (Fig. 2). A slight overlap was seen between $C$. morgani and $P$. varius.

\section{DISCUSSION}

Based on size as well as morphological differences, the 3 species of gordiids included within this study could easily be discriminated by egg string, egg, larva, and cyst morphology. 
TABLE IV. Partial tabulation of principal component analysis of correlation matrix of 8 attributes of gordiid species (only the first 2 principal components (PC) are shown).

\begin{tabular}{lcc}
\hline \multicolumn{1}{c}{ Variable } & PC1 & PC2 \\
\hline Preseptum length & 0.142 & 0.382 \\
Preseptum width & 0.145 & 0.333 \\
Postseptum length & 0.547 & 0.096 \\
Postseptum width & 0.132 & 0.093 \\
Stylet length & 0.044 & -0.111 \\
Stylet width & 0.119 & 0.730 \\
Pseudointestine length & 0.765 & -0.372 \\
Pseudointestine width & 0.203 & 0.390 \\
\% Variance & 88.84 & 3.33 \\
Cumulative & 88.84 & 92.72 \\
\hline
\end{tabular}

Gordius robustus produced the largest larvae, whereas $C$. morgani produced the smallest. Although all 3 species produced larvae with presepta of comparable lengths, large differences were found in the lengths of the postsepta. The postseptum of $G$. robustus was almost 3 times as long as the postseptum of the other 2 species. Thus, the difference in the overall length of larvae appears to stem from the differences in the length of the postseptum (Fig. 3).

Besides size, the structure of the pseudointestine was markedly different between species. Gordius robustus had a single elongated oval structure, subdivided into unequal portions anteriorly (Fig. 3D). This shape and division has also been noted in G. aquaticus (Mühldorf, 1914; Dorier, 1930). The pseudointestine of $P$. varius was also elongate oval in shape but contained a pair of anterior granules and a large posterior mass (Fig. 3E), as described previously (Zapotosky, 1975).

The pseudointestine of $C$. morgani, in contrast, was much

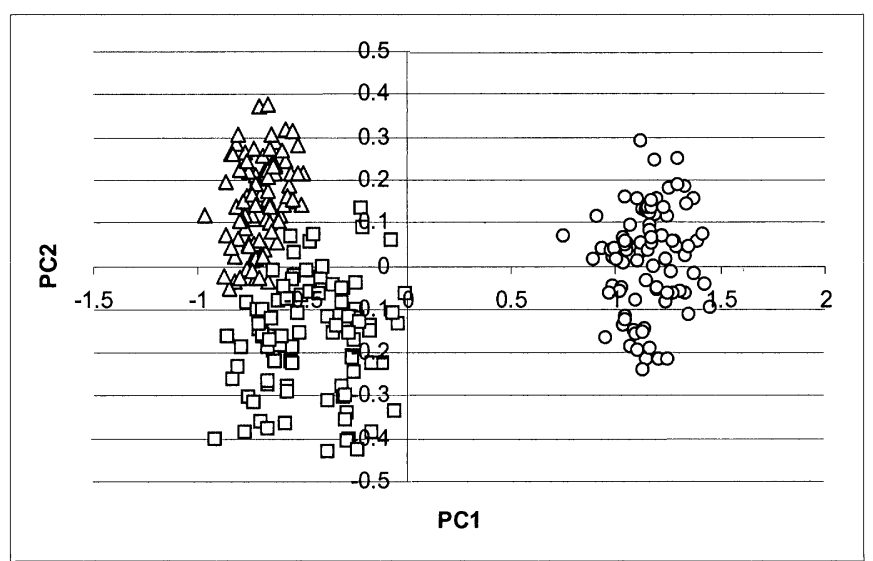

FIGURE 2. Canonical plot of gordiid larvae. Gordius robustus (O), Paragordius varius $(\square)$, and Chordodes morgani $(\triangle)$.

more complex. In this species, the pseudointestine is v-shaped with 1 small and 1 large branch but with both branches pointing anteriorly (Fig. 3F). The larger branch normally pointed slightly ventrally, and the smaller branch usually pointed slightly more dorsally. A large globule was present at the bottom of the pseudointestine and branched into both parts of the pseudointestinal cavity. A smaller globule capped each branch of the large globule. The same structural arrangement has been noted in $C$. japonensis (Inoue, 1958). In addition, a similar arrangement has been reported in Neochordodes occidentalis (Poinar and Doelman, 1974). However, in the latter species, the authors noted the presence of a preintestinal gland, which appeared to be absent in $C$. morgani.

The ultimate function of the pseudointestinal gland is still unclear. Early investigations suggested a reproductive function
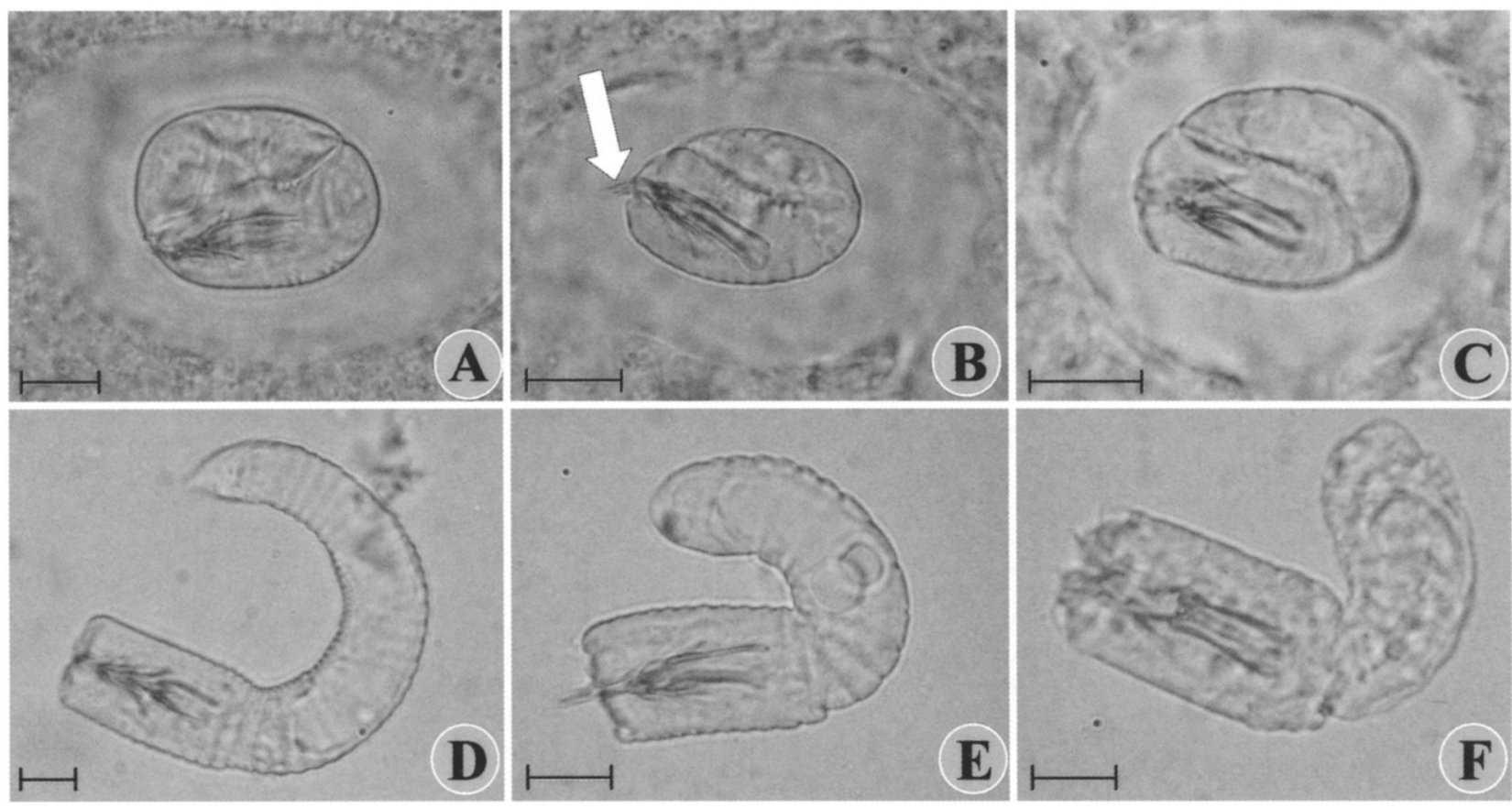

FIGURE 3. Gordiid larvae and cysts. Gordius robustus (A, larva; D, cyst). Paragordius varius (B, larva; E, cyst). Chordodes morgani (C, larva; $\mathbf{F}$, cyst). Scale bar $=10 \mu \mathrm{m}$. Arrow indicates $P$. varius specific hook orientation. 


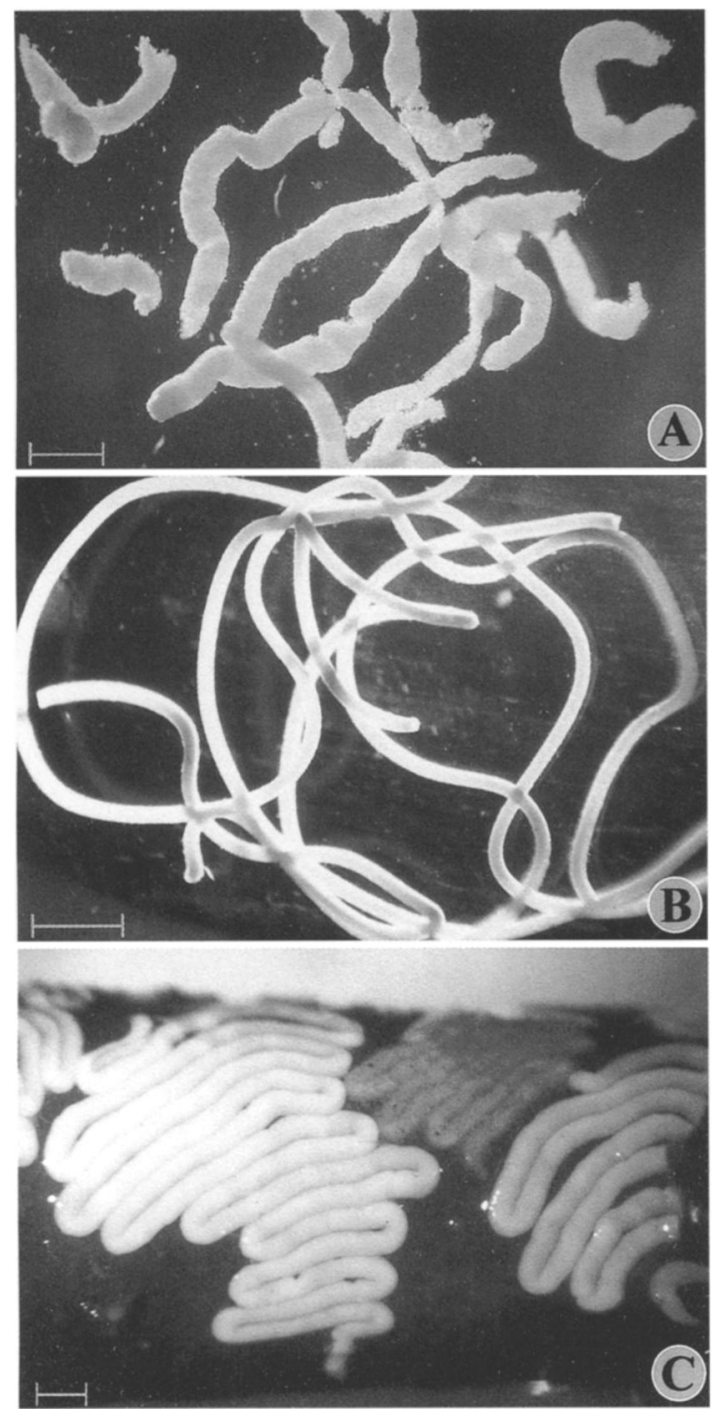

FIGURE 4. Egg strings of (A) Gordius robustus, (B) Paragordius varius, and (C) Chordodes morgani. Scale bar $=1,000 \mu \mathrm{m}$. Note that the egg string of C. morgani is attached to a stick.

(Schepotieff, 1908). However, more recently, the pseudointestine has been suggested to have a function in cyst wall formation (Dorier, 1935; Poinar and Doelman, 1974). In the present study, it was also noted that in all 3 species of gordiids, the pseudointestine is increasingly reduced as larvae age and is greatly reduced or absent altogether after encystment.

Although species discrimination of cysts was possible based on morphometric data, each species also had a unique cyst structure. Because of the size of the postsepum, G. robustus cyst larvae were folded 3 times. Both $P$. varius and $C$. morgani cyst larva were folded only a single time. In addition, $P$. varius cysts had hooks protruding from their preseptum (Fig. 3B), which was lacking in the other 2 species.

The most intriguing difference found between the species was not only in egg string morphology (Fig. 4) but also in ovipositioning strategies. Gordius robustus produced the widest egg strings. These egg strings were very irregular in shape and usually pieces of egg strings were no longer than $3-10 \mathrm{~mm}$. Paragordius varius produced egg strings with the smallest width. These egg strings were often laid in 1 continuous string, up to about $50 \mathrm{~cm}$ in length. In the natural environment, $P$. varius would often "weave" these egg strings into algal mats. More often, however, the egg string of $P$. varius would simply drop to the substrate, as was noted for $G$. robustus.

The egg strings of $C$. morgani were also laid in a longer continuous string, but females attached the egg string to organic or detritus material (Fig. 4C). It was noted in the laboratory and in the natural environment that $C$. morgani adults would only attach and lay eggs onto sticks or smaller branches less than $1 \mathrm{~cm}$ in diameter. Although the cause of these varying ovipositioning strategies is unknown, the specific placement of egg strings (and ultimately the larvae) could lead to the use of different paratenic hosts by different gordiid species. Because aquatic animals have distinct niches, based on their functional feeding groups (scrapers, shredders, scavengers, etc.), habits (burrowers, sprawlers, clingers, etc.), or both, it is conceivable that distinct groups of animals could become despairingly exposed and infected with different gordiid species. For example, scrapers, which selectively feed by scraping the substrate such as rocks and detritus material, may be more likely to be exposed to $C$. morgani than other species of gordiids. Additional evidence is necessary to support these findings.

Results from both DFA and PCA analyses corroborate that the postseptum length, pseudointestine length, and stylet width are critical in discriminating between the larvae of the 3 species of gordiids. However, it should be noted that these data are based on only 3 species, and it may be important to include data from other gordiid species to identify morphological characters that will be useful universally in species-level discrimination.

The present study has focused attention on the nonadult life cycle stages of gordiids. The aforementioned differences in structures between the commonest American gordiid species have several implications. First, differences in egg larva, cyst, egg string, and oviposition behavior widely differ between species of gordiids and thus may be useful in phylogenetic analysis. Second, species can be identified by features other than adult characters, especially those of the cyst stage, which is the most encountered life cycle stage. This finding will make the study of the distribution of specific species of gordiids easier (Hanelt et al., 2001). Third, differences in oviposition behavior may indicate that each species employs a unique repertoire of hosts and thus has a unique life cycle.

We hope that the present study provides an incentive to investigate the nonadult life cycle stages of other gordiids and that the differences in nonadult life cycle stages and behaviors noted earlier in this article will aid in the identification and taxonomy of this group.

\section{ACKNOWLEDGMENTS}

The authors gratefully acknowledge Sara V. Brant and Michelle L. Steinauer for providing critical comments on this manuscript and A. Alan Kocan for supplying worms from Oklahoma. This work was supported by a grant from the Initiative for Ecological and Evolutionary Analysis, University of Nebraska-Lincoln and a Blair Paxton Udale Scholarship from the School of Biological Sciences, University of Nebraska-Lincoln. 


\section{LITERATURE CITED}

Adrianov, A. V., V. V. Malakhov, and S. E. Spiridonov. 1998. Fine morphology of the larvae of hairworm Gordius sp. (Nematomorpha). Doklady Akademii Nauk 361: 558-561.

Aleshin, V. V., I. A. Milyutina, O. S. Kedrova, N. S. VladychenSKAYA, AND N. B. Petrov. 1998. Phylogeny of nematoda and cephalorhyncha derived from 18S rDNA. Journal of Molecular Evolution 47: 597-605.

Bohall, P. J., M. R. Wells, and C. M. Chandler. 1997. External morphology of larvae of Chordodes morgani (Nematomorpha). Invertebrate Biology 116: 26-29.

BRESCIANI, J. 1991. Nematomorpha. In Microscopic anatomy of invertebrates, F. W. Harrison (ed.). Wiley-Liss, Inc., New York, p. 197218.

Chandler, C. M. 1985. Horsehair worms (Nematomorpha, Gordioidea) from Tennessee, with a review of taxonomy and distribution in the United States. Journal of the Tennessee Academy of Sciences 60: $59-62$.

- AND M. R. WELLS. 1989. Cuticular features of Chordodes morgani (Nematomorpha) using scanning electron microscopy. Transactions of the American Microscopical Society 108: 152-158.

DE Miralles, D. A. B., AND L. C. De Villalobos. 1995. A review of the Gordiacea (Nematomorpha) in the collection of the California Academy of Sciences with the description of a new species. Graellsia 51: 17-22.

de Villalobos, C., G. Ramirez, S. Chavarria, and F. Zanca. 2000. Cuticular ultrastructure of Paragordius esavianus Carvalho and $P$. varius (Leidy) (Nematomorpha: Chordodidae: Paragordinae). Proceedings of the Academy of Natural Sciences of Philadelphia 150: 135-144.

DORIER, A. 1930. Recherches biologiques et systématiques sur les Gordiacés. Annales Université de Grenoble 7: 1-183.

- 1935. Sur le passage a la vie latente des larves des Gordiacés. Comptes Rendus de l'Académie des Sciences, Paris 200: 491-494.

Hanelt, B., L. E. Grother, And J. Janovy Jr. 2001. Physid snails as sentinels of freshwater nematomorphs. Journal of Parasitology 87: 1049-1053.

- AND J. JANOVY JR. 1999. The life cycle of a horsehair worm, Gordius robustus (Gordioidea: Nematomorpha). Journal of Parasitology 85: 139-141.

INOUE, I. 1958. Studies on the life history of Chordodes japonensis, a species of Gordiacea. I. The development and structure of the larva. Japanese Journal of Zoology 12: 203-218.

MaLaKhov, V. V. 1980. Cephalorhyncha, a new type of animal kingdom uniting Priapulida, Kinorhyncha, Gordiacea, and a system of Aschelminthes worms. Zoologicheskii Zhurnal 59: 485-499.

MAY, H. G. 1919. Contributions to the life histories of Gordius robustus (Leidy) and Paragordius varius (Leidy). Illinois Biological Monographs 5: 1-119.

MONTGOMERY, T. H., JR. 1898. Descriptions of two new exotic species of the genus Chordodes. Zoologischer Jahresbericht, Anatomie und Ontogonie 11: 379-344.

. 1903. The adult organization of Paragordius varius (Leidy).

Zoologischer Jahresbericht, Anatomie und Ontogonie 18: 387-474.

. 1904. The development and structure of the larvae of Paragordius. Proceedings of the Academy of Natural Sciences 56: 738755.

MüHLDORF, A. 1914. Beiträge zur Erwicklungsgeschichte und zu den phylogenetischen Beziehungen der Gordius Larve. Zeitschrift für wissentschaftliche Zoologie 111: 1-75.

Nielsen, C., N. Scharff, AND D. Eibye-Jacobsen. 1996. Cladistic analyses of the animal kingdom. Biological Journal of the Linnean Society 57: 385-410.

PoINAR, G. O., JR. 1991. Hairworm (Nematomorpha: Gordioidea) parasites of New Zealand wetas (Orthoptera: Stenopelmatidae). Canadian Journal of Zoology 69: 1592-1599.

$\longrightarrow$, AND J. J. Doelman. 1974. A reexamination of Neochordodes occidentalis (Montg.) comb. n. (Chordodidae: Gordioidea): Larval penetration and defense reaction in Culex pipens L. Journal of Parasitology 60: 327-335.

SAS INSTITUTE INC. 1990. SAS/STAT user's guide, 6th ed., vols. 1 and 2. SAS Institute, Cary, North Carolina, $1686 \mathrm{p}$.

SCHEPOTIEFF, A. 1908. Über den feineren Bau der Gordiuslarven. Zeitschrift für wissentschaftliche Zoologie 89: 230-241.

SChmidT-RhaESA, A. 1997/98. Phylogenetic relationships of the Nematomorpha-A discussion of current hypothesis. Zoologischer Anzeiger 236: 203-216.

SMITH, D. G. 1991. Observations on the morphology and taxonomy of two Parachordodes species (Nematomorpha, Gordioidea, Chordodidae) in southern New England (USA). Journal of Zoology 225: $469-480$.

-1994. A reevaluation of Gordius aquaticus difficilis Montgomery 1898 (Nematomorpha, Gordioidea, Gordiidae). Proceedings of the Academy of Natural Sciences of Philadelphia 145: 29-34.

Wallace, R. L., C. Ricci, and G. Melone. 1996. A cladistic analysis of pseudocoelomate (aschelminth) morphology. Invertebrate Biology 115: 104-112.

WinnePenNinckX, B., T. BackeljaU, L. Y. Mackey, J. M. Brooks, R. De Wachter, S. Kumar, AND J. R. Garey. 1995. 18S rRNA data indicate that Aschelminthes are polyphyletic in origin and consist of at least three distinct clades. Molecular Biology and Evolution 12: 1132-1137.

ZAPOTOSKY, J. E. 1974. Fine structure of the larval stage of Paragordius varius (Leidy, 1851) (Gordioidea: Paragordidae). I. The preseptum. Proceedings of the Helminthological Society of Washington 41: 209-221.

. 1975. Fine structure of the larval stage of Paragordius varius (Leidy 1851) (Gordioidea: Paragordidae). Proceedings of the Helminthological Society of Washington 42: 103-111.

Zrzavý, J., S. Minulka, P. KePKA, A. BeZdek, AND D. Tietz. 1998. Phylogeny of the metazoa based on morphological and $18 \mathrm{~S}$ ribosomal DNA evidence. Cladistics 14: 249-285. 